\title{
From nephron to neuron: an exciting journey in search of a cure for epilepsy
}

\author{
Carlos de Cabo* \\ Neuropsychopharmacology Unit, Albacete General Hospital, Albacete, Spain
}

Epilepsy is a serious neurological condition that affects about $1 \%$ of the world population and therefore represents a health issue of public concern. Despite the intensive research and clinical work carried out for years in this field, there are types of epilepsy that remain untreatable and some treatments are accompanied by undesirable side-effects. This is due, at least in part, to the fact that the causes of epileptic seizures have not been fully elucidated. Seizures take place when a group of excitatory neurons start firing synchronically in an uncontrolled fashion in the brain. Neuronal communication is regulated via a complex balance of excitatory and inhibitory inputs. If this equilibrium is altered due to hyperexcitation or reduced inhibition, uncontrolled excitatory discharges may occur leading to an epileptic seizure. Seizures may manifest as positive signs corresponding to the function of the area where those neurons belong (focal or partial seizures), or they may even recruit other neuronal groups, reaching the ascending and descending reticular system and leading to generalized seizures. Our knowledge about the cellular and molecular mechanisms underlying epileptic seizures is still limited and often we are not certain as to what conditions or alterations lead to an epileptic brain. In recent years, the idea is gaining strength that impairment of the inhibitory systems could be at the root of epileptic seizures [1]. More specifically, a crucial role has been proposed for interneurons secreting $\gamma$-Aminobutyric acid (GABA) as their primary neurotransmitter [24]. GABA amino acid neurotransmitter is responsible for most of the fast-inhibitory neurotransmission in the brain by acting on its putative ionotropic receptors type $A\left(G A B A_{A} R\right)$. $G_{A B A}$ Rs are ligand-operated $\mathrm{Cl}^{\text {in }}$ ion channels. GABA binding to $\mathrm{GABA}_{A} \mathrm{R}$ leads to the opening of the channel allowing the entrance of $\mathrm{Cl}^{-}$inside the neuron causing a hyperpolarization of the postsynaptic membrane. Thus, for GABA actions to be effective $\mathrm{Cl}^{-}$levels have to be lower inside the neuron. The main molecules responsible for maintaining suitable $\mathrm{Cl}^{-}$levels are cation / $\mathrm{Cl}^{-}$cotransporters. $\mathrm{Na}+/ \mathrm{K}+/ \mathrm{Cl}^{-}$cotransporter (NKCC1) introduces $\mathrm{Cl}^{-}$inside the cell, whereas the $\mathrm{K}+/ \mathrm{Cl}-$ cotransporter (KCC2) transports $\mathrm{Cl}^{-}$outside the cell keeping $\mathrm{Cl}^{-}$levels below its electrochemical potential equilibrium, allowing an inward current when GABA binds the GABA $\mathrm{R}$. NKCC1 is expressed in both neurons and glial cell whereas KCC2 is only expressed in neurons. During development NKCC1 has been shown to be expressed in high levels while KCC2 levels are low at birth and they increase during postnatal development. This exchange in NKCC1 / KCC2 expression leads to higher $\mathrm{Cl}^{-}$levels inside the neuron and therefore GABA binding to GABA Rs results in membrane depolarization during the neonatal stages [5-7]. Interestingly, alterations in NKCC1 / KCC2 balance have also been described in epilepsy, both in patients and animal models [4,8-14]. This evidence has led to the hypothesis that an imbalance in the expression of these cotransporters may be at the origin of various types of epilepsies and could be considered as new therapeutical targets. In this regard, it is worth mentioning that other members of these families of cotransporters exist in the nephron (KCC1, KCC3, KCC4, NKCC2) where they are also in charge of ion exchange at this level [15]. These molecules have already been targeted for kidney related disorders with the use of "loop diuretics" such as furosemide (blocking the KCC cotransporters) and bumetanide (blocking NKCC cotransporters) [1]. In this way, Nephrology studies provided us with new tools to act in the brain. This approach has already been employed for epilepsy research both in experimental studies and clinical trials [16-18]. Further, more recent studies in the nephron have provided new information about the molecular activity-dependent mechanisms regulating the activation /deactivation of both KCC and NKCC type cotransporters and the interconnections between them. SPAK (Ste20-related proline alanine-rich kinase) and OSR1 (oxidative stress response 1) kinases phosphorylate and activate NKCC, while they have the opposite effect on KCC. SPAK/OSR1 act in combination with the WNK (With No lysine $=$ K) type kinases (WNK1-4). SPAK/OSR1 and $\mathrm{WNK}$ act as intracellular $\mathrm{Cl}^{-}$sensors reducing their activity when $\mathrm{Cl}^{-}$concentration decreases, thus closing the regulatory loop [19-20]. The kinases involved in this complex regulation of Cl- intracellular concentration at the nephron level, may represent not only new therapeutic targets for kidney dysfunction, but also a new field for research in epilepsy. Indeed, SPAK/OSR1 and WNKs kinases have been described in neurons regulating NKCC and KCC2 cotransporter activity in a similar way as they do in the nephron [21-27]. Previous studies have shown that peripherally administered loop diuretics targeting $\mathrm{K}+/ \mathrm{Cl}-$ cotransporters can effectively reach the brain [16, 26], although current research is focusing on finding compounds with better bioavailability to the brain and, hopefully, fewer side effects [17, 28]. Another promising line of research is looking at inhibiting SPAK/ OSR1 and WNKs kinases. Some success has already been achieved using in vitro techniques and genetic (knock out, RNAi) mouse models [22- 26], but so far, no compounds targeting these kinases have been tested in vivo. Future studies will be necessary to determine whether new therapies for the epilepsies will come at the end of this intriguing research journey from nephron to neuron.

Correspondence to: Carlos de Cabo, Hospital General Universitario de Albacete, Unidad de Neuropsychopharmacology, Research Building, $3^{\text {a }}$ planta, c/ Hermanos Falcó, 37, E-02006, Albacete, Spain; Tel: + (34) 967 597500; Fax: + (34) 967 243952; E-mail: carlosd@sescam.jccm.es

Received: September 16, 2017; Accepted: October 10, 2017; Published: October 14, 2017 


\section{Funding}

CdC received support from FIS-FEDER [grant numbers 01/3018, PS09/01154] and JCCM, Consejería de Sanidad [grant numbers 0404800, GC 05011]. The funding bodies played no role in design, collection, analysis, or interpretation of data; nor in the writing of the manuscript; nor in the decision to submit the manuscript for publication.

\section{References}

1. de Cabo-de la Vega C, Villanueva-Hernández P, Prieto-Martín A (2006) The neurochemistry of epilepsy, inhibitory neurotransmission and experimental models: new perspectives. Rev Neurol 42: 159-168. [Crossref]

2. Cossart R, Bernard C, Ben-Ari Y (2005) Multiple facets of GABAergic neurons and synapses: multiple fates of GABA signalling in epilepsies. Trends Neurosci 28: 108115. [Crossref]

3. María Carmen Carrascosa-Romero, Carlos De Cabo De La Vega (2016) GABAergic Interneurons in Severe Early Epileptic Encephalopathy with a Suppression-Burst Pattern: A Continuum of Pathology. In Kalinin V (Ed). Epileptology-The Modern State of Science, Croatia: InTech Open Access Publisher; Chapter 3, pp. 45-104.

4. Prieto-Martín AI, Aroca-Aguilar JD, Sánchez-Sánchez F, Muñoz LJ, López DE, et al. (2017) Molecular and neurochemical substrates of the audiogenic seizure strains: The GASH: Sal model. Epilepsy Behav 71: 218-225. [Crossref]

5. Dzhala VI, Talos DM, Sdrulla DA, Brumback AC, et al. (2005) NKCC1 transporter facilitates seizures in the developing brain. Nat Med 11: 1205-1213. [Crossref]

6. Andäng M, Lendahl U (2008) Ion fluxes and neurotransmitters signaling in neural development. Curr Opin Neurobiol 18: 232-236. [Crossref]

7. Pfeffer CK, Stein V, Keating DJ, Maier H, Rinke I, et al. (2009) NKCC1-dependent GABAergic excitation drives synaptic network maturation during early hippocampal development. J Neurosci 29: 3419-3430. [Crossref]

8. Dzhala VI, Kuchibhotla KV, Glykys JC, Kahle KT, Swiercz WB, et al. (2010) Progressive NKCC1-dependent neuronal chloride accumulation during neonatal seizures. J Neurosci 30: 11745-11761. [Crossref]

9. Aronica E, Boer K, Redeker S, Spliet WGM, Van Rijen C, et al. (2007) Differential expression patterns of chloride transporters, $\mathrm{Na}+/ \mathrm{k}+/ 2 \mathrm{cl}$ - cotransporter and $\mathrm{K}+/ \mathrm{Cl}-$ cotransporter, in epilepsy-associated malformations of cortical development. Neurosci 145:185-196. [Crossref]

10. Sen A, Martinian L, Nikolic M, Walker MC, Thom M, et al. (2007) Increased NKCC1 expression in refractory human epilepsy. Epilepsy Res 74: 220-227. [Crossref]

11. Muñoz A, Méndez P, DeFelipe J, Alvarez-Leefmans FJ (2007) Cation-chloride cotransporters and GABA-ergic innervation in the human epileptic hippocampus. Epilepsia 48: 663-673. [Crossref]

12. Puskarjov M, Seja P, Heron SE, Williams TC, et al. (2014) A variant of KCC2 from patients with febrile seizures impairs neuronal $\mathrm{Cl}$ - extrusion and dendritic spine formation. EMBO Rep 15: 723-729. [Crossref]
13. Kahle KT, Merner ND, Friedel P, Silayeva L, Liang B, Khanna A, et al. (2014) Genetically encoded impairment of neuronal $\mathrm{KCC} 2$ cotransporter function in human idiopathic generalized epilepsy. EMBO Rep 15: 766-774. [Crossref]

14. Kahle KT, Khanna AR, Duan J, Staley KJ, Delpire E, et al. (2016) The KCC2 Cotransporter and Human Epilepsy: Getting Excited About Inhibition. Neuroscientist 22: 555-562. [Crossref]

15. Boettger T, Hübner CA, Maier H, Rust MB, Beck FX, et al. (2002) Deafness and renal tubular acidosis in mice lacking the K-Cl co-transporter Kcc4. Nature 416: 874-878. [Crossref]

16. Dzhala VI, Brumback AC, Staley KJ (2008) Bumetanide enhances phenobarbital efficacy in a neonatal seizure model. Ann Neurol 63: 222-235. [Crossref]

17. Erker T, Brandt C, Töllner K, et al. (2016) The bumetanide prodrug BUM5, but not bumetanide, potentiates the antiseizure effect of phenobarbital in adult epileptic mice. Epilepsia 57: 698-705. [Crossref]

18. Soul, Janet (2017) Pilot Study of Bumetanide for Newborn Seizures.

19. de Los Heros P, Alessi DR, Gourlay R, Campbell DG, Deak M, et al. (2014) The WNK-regulated SPAK/OSR1 kinases directly phosphorylate and inhibit the K+-Clco-transporters. Biochem J 458: 559-573. [Crossref]

20. Markadieu N, Rios K, Spiller BW, McDonald WH, Welling PA, et al. (2014) Shor forms of Ste20-related proline/alanine-rich kinase (SPAK) in the kidney are created by aspartyl aminopeptidase (Dnpep)-mediated proteolytic cleavage. J Biol Chem 289: 29273-29284. [Crossref]

21. Piechotta K, Lu J, Delpire E (2002) Cation chloride cotransporters interact with the stress-related kinases Ste20-related proline-alanine-rich kinase (SPAK) and oxidative stress response 1 (OSR1). J Biol Chem 277: 50812-50819. [Crossref]

22. Inoue $\mathrm{K}$, Furukawa T, Kumada T, Yamada J, Wang T, et al. (2012) Taurine inhibits $\mathrm{K}+-\mathrm{Cl}$ - cotransporter $\mathrm{KCC} 2$ to regulate embryonic $\mathrm{Cl}$ - homeostasis via with-no-lysine (WNK) protein kinase signaling pathway. J Biol Chem 287: 20839-20850. [Crossref]

23. Rinehart J, Vázquez N, Kahle KT, Hodson CA, Ring AM, et al. (2011) WNK2 kinase is a novel regulator of essential neuronal cation-chloride cotransporters. $J$ Biol Chem 286: 30171-30180. [Crossref]

24. Medina I, Friedel P, Rivera C, Kahle KT, Kourdougli N, et al. (2014) Current view on the functional regulation of the neuronal $\mathrm{K}(+)-\mathrm{Cl}(-)$ cotransporter $\mathrm{KCC} 2$. Front Cell Neurosci 8: 27. [Crossref]

25. Alessi DR, Zhang J, Khanna A, Hochdörfer T, Shang Y, et al. (2014) The WNK-SPAK OSR1 pathway: master regulator of cation-chloride cotransporters. Sci Signal 7: re3. [Crossref]

26. Kahle KT, Khanna AR, Alper SL, Adragna NC, Lauf PK, et al. (2015) K-Cl cotransporters, cell volume homeostasis, and neurological disease. Trends $\mathrm{Mol} \mathrm{Med}$ 21: 513-523. [Crossref]

27. Rodan AR, Jenny A (2017) WNK Kinases in Development and Disease. Curr Top Dev Biol 123: 1-47. [Crossref]

28. Glykys J, Dzhala V, Egawa K, Kahle KT, Delpire E, et al. (2017) Chloride Dysregulation, Seizures, and Cerebral Edema: A Relationship with Therapeutic Potential. Trends Neurosci 40: 276-294. [Crossref]

Copyright: $\bigcirc 2017$ Carlos de Cabo. This is an open-access article distributed under the terms of the Creative Commons Attribution License, which permits unrestricted use, distribution, and reproduction in any medium, provided the original author and source are credited. 